\title{
RESULTS OF ALENDRONATE TREATMENT IN PATIENTS DIAGNOSED WITH ASEPTIC OSTEONECROSIS OF THE FEMORAL HEAD
}

\author{
KAMAL CONSTANTIN KAMAL ${ }^{1 \#}$, DRAGOȘ OVIDIU ALEXANDRU ${ }^{2 *}$, OTILIA CONSTANTINA \\ ROGOVEANU $^{3}$, DIANA KAMAL ${ }^{4 *}$, ALICE SANDRA BUTEICĂ ${ }^{5 *}$, TUDOR ADRIAN BĂLŞEANU ${ }^{6}$, \\ CAMELIA PĂNUȘ ${ }^{7}$, DANIELA TEODORA MARIA ${ }^{8 \#}$, MAGDALENA RODICA TRĂISTARU ${ }^{3}$ \\ ${ }^{1}$ Family Medicine Department, University of Medicine and Pharmacy of Craiova, 2-4 Petru Rares St., 200349, Craiova, Romania \\ ${ }^{2}$ Department of Medical Informatics and Biostatistics, University of Medicine and Pharmacy of Craiova, 2-4 Petru Rares St., \\ 200349, Craiova, Romania \\ ${ }^{3}$ Physical and Rehabilitation Medicine Department, University of Medicine and Pharmacy of Craiova, 2-4 Petru Rares St., \\ 200349, Craiova, Romania \\ ${ }^{4}$ Physical and Rehabilitation Medicine Department, Medical Clinic Elga, University of Medicine and Pharmacy of Craiova, \\ 2 Mihai Eminescu Str., 200131, Craiova, Romania \\ ${ }^{5}$ Faculty of Pharmacy, University of Medicine and Pharmacy of Craiova, 2-4 Petru Rares St., 200349, Craiova, Romania \\ ${ }^{6}$ Department of Physiology, University of Medicine and Pharmacy of Craiova, 2-4 Petru Rares St., 200349, Craiova, Romania \\ ${ }^{7}$ Department of Diabetes, Nutrition and Metabolic Disease, Emergency Clinical County Hospital of Craiova, University of \\ Medicine and Pharmacy of Craiova, 1Tabaci St., 200642, Craiova, Romania \\ ${ }^{8}$ Nephrology Department, University of Medicine and Pharmacy of Craiova, 2-4 Petru Rares St., 200349, Craiova, Romania
}

*corresponding author: dragosado@yahoo.com

\#authors with equal contribution

Manuscript received: July 2018

\begin{abstract}
Aseptic osteonecrosis of the femoral head is a disabling condition with plurifactorial aetiology, which affects especially young adults. The purpose of the study was to show that alendronate therapy is useful to these patients. We included 34 patients aged 23 to 62 years old, diagnosed in the evolutionary stages II and III, which were divided into two groups. Patients in the first group received treatment with alendronate- $70 \mathrm{mg}$ per week plus $5600 \mathrm{IU}$ cholecalciferol for 2 years and conservative treatment. Group II was not treated with alendronate but only conservatively treated. Patients were evaluated from a clinical, imagistic and functional standpoint. In the final evaluation, the imaging aspects improved in patients in the first group. The dual-energy x-ray absorptiometry (DXA) T score, the visual analogue scale (VAS) and the Harris Hip test statistically increased significantly in patients in the first group.
\end{abstract}

\section{Rezumat}

Osteonecroza aseptică de cap femural este o afecțiune invalidantă, cu etiologie plurifactorială, ce afectează cu precădere adulții tineri. Scopul studiului a fost acela de a arăta că terapia cu alendronat este utilă acestor pacienți. Am inclus în studiu 34 de pacienți, cu vârste cuprinse între 23 și 62 de ani, diagnosticați în stadiile evolutive II și III, ce au fost împărțiţi în 2 loturi. Pacienții din primul lot au beneficiat de tratament cu alendronat- $70 \mathrm{mg}$ pe săptămână plus 5600 UI colecalciferol timp de 2 ani și tratament conservator. Lotul II nu a primit tratament $\mathrm{cu}$ alendronate, ci a beneficiat doar de tratament conservator. Pacienții au fost evaluați clinic, imagistic și funcțional. La evaluarea finală, aspectele imagistice s-au ameliorat la pacienții din primul grup. Scorul T al absorțiometriei duale cu raze X (DXA), cel al scalei analog vizuale a durerii (VAS) şi al testului Harris Hip au crescut semnificativ din punct de vedere statistic la pacienții din primul lot.

Keywords: aseptic osteonecrosis, femoral head, alendronate

\section{Introduction}

Aseptic osteonecrosis of the femoral head (AVN) is a disabling condition with plurifactorial aetiology, which affects predominantly young adults $[12,19]$. The prevalence of the disease is unknown, but between 10000 and 20000 new cases of femoral aseptic osteonecrosis are diagnosed annually in the United States [5, 15, 27]. Although the pathogenesis of the disease is not fully elucidated, it is recognized that the triggering phenomenon is represented by partial or total disruption of the femoral head vascularization. Lack of vascularity at this level causes death of bone marrow and bone cells [10, 11, 20, 21]. The collapse of bone tissue translates into localized pain and loss of function of the affected coxo-femoral joint, most patients requiring surgery within 3 - 5 years of being diagnosed, in the form of a bipolar or total hip arthroplasty. Because many of the patients diagnosed with this condition are young adults, hip prothesis must be the last therapeutic option, taking into consideration the fact that they last only a few 
years, requiring periodic adjustment and inspection, therefore, when feasible, attempts should be made to save the femoral head prior to collapse with the use of less invasive treatment options [17]. Bisphosphonates (Bps) are potent anti-reabsorbent agents that act by inhibiting the action of mature osteoclasts in the bone, which theoretically normalizes uncoupled bone remodelling, contributing to femoral head collapse $[8,13,14]$. Of different Bps, alendronate is the most widely prescribed and obvious one [15]. Alendronic acid or alendronate is a nitrogen-containing, second generation bisphosphonate, that binds to and inhibits the activity of farnesyl pyrophosphate synthetase, preventing this way the alterations of small GTPase signalling proteins, which have an important role in speeding up the osteoclast turnover. As a result, bone resorption and turnover are reduced.

The purpose of the study was to determine the role that alendronate therapy has in the treatment of the patients diagnosed with this condition.

\section{Materials and Methods}

A randomized blind study was conducted over two years (Jan 2015 - Dec 2017). We included 34 patients aged between 23 and 62 years old, diagnosed with aseptic osteonecrosis of the femoral head, in the evolutionary stages II and III (Liver and Arlet staging), admitted in the Physical and Rehabilitation Medicine Department of the Municipal Hospital "Filantropia" Craiova, Romania. The inclusion criteria consisted in a diagnosis for aseptic necrosis of the femoral head, a modified $\mathrm{T}$ dual-energy $\mathrm{x}$-ray absorptiometry (DXA) score, and the visualization of an alteration of the femoral head histoarchitecture. The exclusion criteria were represented by a normal $\mathrm{T}$ DXA score, as well as minimal changes in bone tissue structure surrounding the affected area, and the pre-existence of another condition that could have caused the loss of bone mass.

The patients were divided into two groups. Group I16 patients treated with alendronate-70 mg per week plus 5600 IU cholecalciferol (vitamin D) for 2 years and other means of conservative treatment hygiene-dietary measures, lifestyle changes, wearing walking aids, physiotherapy, kinetotherapy. Group II, 18 patients without treatment with alendronate, only with conservative treatment. Patients in both groups also benefited from pain medication if needed. In order to monitor the therapeutic outcomes, patients were clinically and paraclinically evaluated at study inclusion and at the end of the study. Paraclinic investigations were represented by the collection of several common blood tests, blood inflammation markers such as erythrocyte sedimentation rate (ESR), fibrinogen, $C$ reactive protein (CRP), and other blood tests like calcium level, vitamin $\mathrm{D}$, thyroid tests - tyroid-stimulating hormone level (TSH), para- thyroid hormone level, protein electrophoresis, alkaline phosphatase, performed in the hospital lab and imaging techniques. Commercial kits and biochemical methods used to determine biochemical parameters were the following: for the haematological parameters the hospital lab used automatic blood count BM-800, for fibrinogen STAGO kit was by the coagulometry method, for ESR- graduated sedimentation rack with vertical test tubes. For the biochemical parameters the lab used the KONELAB60I kit, using a spectrophotometric method and for CRP the Manual Imuno kit. The bone mineral density assessment, initially and at the end of the study, was performed using imaging techniques: X-rays, MRI (magnetic resonance imaging), computed tomography (CT) and DXA test. Pain intensity evaluation was performed using the VAS analogue-visual (VAS) pain scale, and the functionality was evaluated using the Harris Hip scale.

The study has obtained approval from the Ethics Committee of the University of Medicine and Pharmacy of Craiova, Romania, number 217/24.11.2017. Each patient signed an informed consent, they were previously handed a form in which they were presented all the information related to the participation in the study. Clinical data and the collection of biological material were achieved after obtaining the written informed consent from the patients.

\section{Results and Discussion}

In the two groups, 34 patients were diagnosed with aseptic osteonecrosis of the femoral head with mixedtraumatic and non-traumatic aetiology, Stages II and III, Ficat and Arlet, aged 23 to 62 years old, with an average age of 43.94 years. The study group was composed of 25 men and 9 women with a sex ratio male:female of $3: 1$. The results of laboratory blood tests were normal in almost all the patients included in the study, except ESR, fibrinogen, alkaline phosphatase, gamma glutamyl transferase, glutamic oxaloacetate transferase (GOT), glutamic pyruvate transaminase (GPT), total cholesterol in 5 patients who showed slightly increased values, without diagnostic value for other conditions that could have triggered loss of bone mass.

Following initial imaging evaluation, changes in bone tissue from the affected hip, in some cases to the contralateral, such as bone loss, increased bone transplantation, and loss of trabecular structure were noted. In the final evaluation, both on X-rays and on MRI images, these aspects improved in several patients from the first group. In patients in whom we noticed an improvement in bone structure, we noticed that the trabecular bone matrix began to recover, gaining more or less regular appearance with the persistence of some of the initial deformities, the 
articular space was preserved or subjected to minimal changes.

Imaging investigations are the basis for the diagnosis and subsequent assessment of patients with this condition. Radiographic, aseptic osteonecrosis have a common element - the emergence of a well-defined condensation zone, or isolated through a peripheral area of reduced intensity. MRI is the non-invasive imaging technique with the highest degree of specificity and sensitivity used in the diagnosis of femoral head aseptic necrosis [21].

Being more quantifiable, we compared the distributions of the two groups according to the T DXA score (Figure 1), and we found that in group I there was a statistically significant improvement ( $\mathrm{p}$ Chi square $=$ $0.026<0.05$ ), while, for group II, the observed differences were not significant $(\mathrm{p}$ Chi square $=$ $0.870>0.05)$.

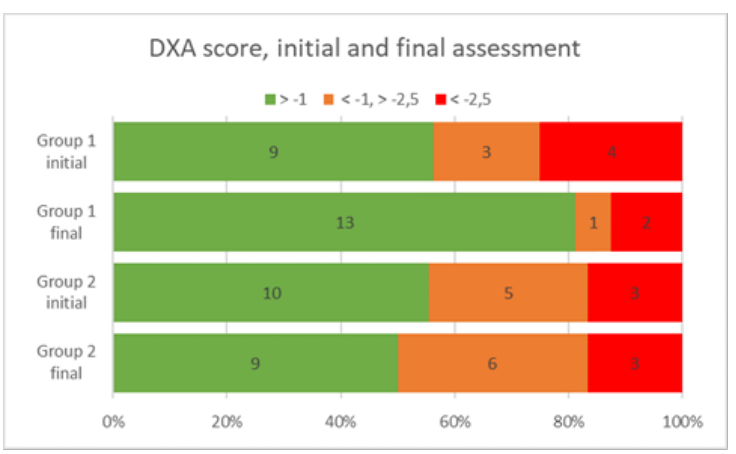

Figure 1.

DXA test, T score values

The DXA test is considered the gold standard in identifying qualitative and quantitative changes in bone tissue, especially in patients experiencing rapid bone loss, being very useful in selecting patients with pharmacological treatment as well as monitoring the effectiveness of anti-resorptive therapy.

Femoral head aseptic osteonecrosis affects especially young adults between the $3 \mathrm{rd}$ and $5^{\text {th }}$ decades of life. $[8,12,14,24]$ It is considered that the average age of patients diagnosed with this condition at the time of the first hip arthroplasty is 38 years [8]. It affects 4 times more men than women [14, 24].

The purpose of the treatment in osteonecrosis of the femoral head, based on the evolutionary stage, is to stop the lesion evolution, to prevent femoral head collapse and to prevent the occurrence of arthrosis changes [14]. There is no general consensus regarding the preclinical treatment of femoral aseptic necrosis [16], but patients, regardless of their aetiology, should be encouraged, even at an early stage, to stop drinking and smoking. Pharmacological treatment in the incipient stages is achieved by the use of cholesterollowering drugs, anticoagulants, vasodilators and bisphosphonates $[9,17,25,26]$. In the last decade, many studies have investigated the application of
Bps in the treatment of AVN $[1-4,6,7,12,15,18$, $22,23,28]$. Alendronic acid seems to be quite effective in preventing early collapse of the femoral head in patients diagnosed early in the disease [3], it has a high affinity for bone mineral and is taken up during osteoclast resorption.

We compared our results with those obtained in similar studies that target patients diagnosed with aseptic osteonecrosis of different aetiologies, stage II and III classified by X-ray and IRM images, according to Ficat and Arlet classification.

In a study conducted by Agarwala et al. in 2011, in which patients diagnosed in stage III AVN received alendronate treatment - $70 \mathrm{mg}$ weekly plus calcium and vitamin $\mathrm{D}$, for 3 years, it was demonstrated that alendronate would delay progression of AVN and avoid early indication of surgery in mid-term follow-up [18]. Other studies by Nishii et al. two groups of patients were compared - in the first were included patients who received alendronate $10 \mathrm{mg}$ per day without any walking assistance versus the second group of patients in which patients did not receive alendronate or walking assistance either. They observed that the patients who had received alendronate had less pain and a lower frequency of femoral head collapse when compared to the control group [4].

VAS scores (Figure 2), were similar at the initial evaluation for all the patients included in the study regardless of the group they were in $(p=0.386)$, which allowed us to compare the effect of the two treatments. While both groups showed an improvement in VAS values, the decrease for the first group was greater than the second one $(\mathrm{p}=0.000846$ versus $\mathrm{p}=$ 0.000728 ), which is also emphasized by the decrease of $p$ values when comparing the VAS scores at the end of the trial $(p=0.110>0.005$ - non-significant difference).

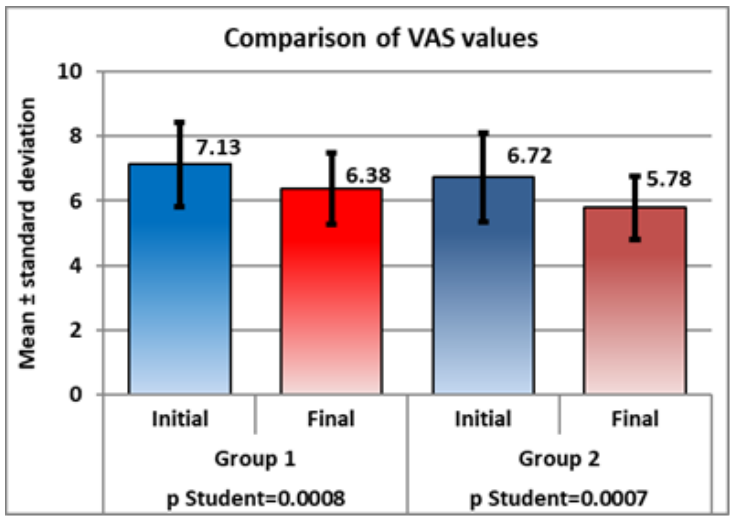

Figure 2.

Comparison of VAS values

As for the Harris Hip Score values, there was no significant difference between the two groups at the initial evaluation $(p=0.189)$, which allows us to 
FARMACIA, 2019, Vol. 67, 2

compare the effect of the two treatments. While both groups showed an improvement in the Harris hip score, the incidence for the first group was higher than the second one $(\mathrm{p}=0.000005$ versus $\mathrm{p}=$ 0.042).

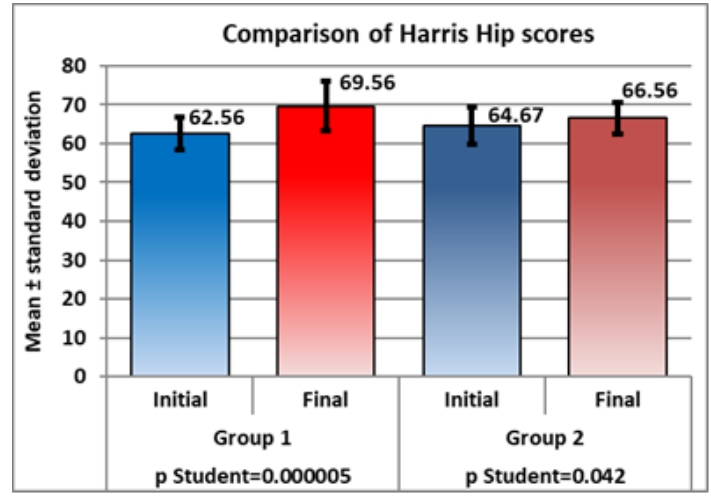

Figure 3.

Comparison of Harris Hip score values

When comparing the VAS values with the Harris hip score, we can conclude that the functional benefits and perceived pain relief were greater for the first group. Chen et al. published a study on the clinical efficacy of alendronate treatment of early-stage adult non-traumatic avascular necrosis of femoral head conducted in 2011 in which patients who received $70 \mathrm{mg}$ of alendronate weekly for 3 months showed improved Harris Hip Score and VAS score. They also concluded that alendronate is effective in the treatment of early adult non-traumatic AVN [2]. Another clinical study conducted by Lai et al. showed a better Harris Hip Score and VAS score in patients who received alendronate $10 \mathrm{mg}$ per day for a period of 2 years. Also, alendronate seemed to prevent the early collapse of the femoral head in the hips [1].

\section{Conclusions}

We consider that the treatment with alendronate in patients diagnosed with aseptic osteonecrosis of the femoral head, regardless of age and aetiology, may play an important role in slowing down bone destruction in the affected area and appears to prevent early femoral head collapse in patients diagnosed in the incipient stages of this condition. The treatment with alendronate increases the functionality and reduces the perceived pain of the patients.

\section{References}

1. Agarwala S, Sule A, Pai BU, Joshi VR, Alendronate in the treatment of avascular necrosis of the hip. Rheumatology, 2002; 41(3): 346-347.

2. Agarwala S, Jain D, Joshi VR, Sule A, Efficacy of alendronate, a bisphosphonate, in the treatment of AVN of the hip. A prospective open-label study. Rheumatology, 2005; 44(3): 352-359.
3. Agarwala S, Shah S, Joshi VR, The use of alendronate in the treatment of avascular necrosis of the femoral head: follow-up to eight years. $J$ Bone Joint Surg Br., 2009; 91(8): 1013-1018.

4. Agarwala S, Shah SB, Ten-year follow-up of avascular necrosis of femoral head treated with alendronate for 3 years. J Arthroplasty, 2011; 26(7): 1128-1134.

5. Babis GC, Sakellariou V, Parvizi J, Soucacos P, Osteonecrosis of the femoral head. Orthopaedics, 2011; 43(1): 39-48.

6. Cardazo JB, Andrade DM, The use of bisphosphonate in the treatment of avascular necrosis: a systematic review. Clin Rheumatol., 2008; 27(6): 685-688.

7. Chen $\mathrm{CH}$, Chang JK, Lai KA, Alendronate in the prevention of collapse of the femoral head in nontraumatic osteonecrosis: a two-year multicenter, prospective, randomized, double-blind, placebocontrolled study. Arthritis Rheum., 2012; 64(5): 1572-1578.

8. Ettienne G, Mont MA, The diagnosis and treatment of nontraumatic osteonecrosis of the femoral head. Instr Course Lect., 2004; 53: 67-85.

9. Garino JP, The treatment of avascular necrosis of the femoral head- a commentary. Univ Peenylv Orthop J., 2000; 13: 96.

10. Kamal D, Alexandru DO, Kamal KC, Streba CT, Grecu DC, Mogoantă L, Macroscopic and microscopic findings in avascular necrosis of the femoral head. Rom J Morphol Embryol., 2012; 53(3): 557-561.

11. Kamal D, Trăistaru MR, Alexandru DO, Kamal CK, Pirici D, Pop OT, Mălăescu DG, Morphometric findings in avascular necrosis of the femoral head. Rom J Morphol Embryol., 2012; 53(Suppl3): 763-767.

12. Kamal D, Trăistaru MR, Kamal KC, Alexandru DO, Ion DA, Grecu DC, Macrophage response in patients diagnosed with aseptic necrosis of the femoral head presenting different risk factors. Rom J Morphol Embryol., 2015; 56(1): 163-168.

13. Kaushik AP, Das A, Cui Q, Osteonecrosis of the femoral head: an update in year 2012. World $J$ Orthop., 2012; 3(5): 49-57.

14. Lai KA, Shen WJ, Yang CY, The use of alendronate to prevent early collapse of the femoral head in patients with nontraumatic osteonecrosis. A randomized clinical study. J Bone Joint Surg Am., 2005; 87(10): 2155-2159.

15. Lieberman JR, Berry DJ, Mont MA, Aaron RK, Osteonecrosis of the hip in the 21st century. Instr Course Lect., 2003; 52: 337-355.

16. Luo RB, Lin T, Zhong HM, Yan SG, Wang JA, Evidence for using alendronate to treat avascular necrosis of the femoral head: a systematic review. Med Sci Monit., 2014; 20: 2439-2447.

17. Malizos KN, Karantanas AH, Osteonecrosis of the femoral head: etiology, imaging and treatment. Eur J Radiol., 2007; 63: 16-28.

18. Marker DR, Seyler TM, Treatment of early stage osteonecrosis of the femoral head. $J$ Bone Joint Surg Am., 2008; 90(Supp14): 175-187.

19. Niishii T, Sugano N, Miki H, Does alendronate prevent collapse in osteonecrosis of the femoral head?. Clin Orthop Relat Res., 2006; 443: 273-279. 
20. Huangfu Q, Li M, Xiao L, Tao H, Wang W, Fei X, Effect of inhaled glucocorticoids on chronic obstructive pulmonary disease in male patients with osteoporosis. Farmacia, 2018; 66(1): 70-77..

21. Santorini FS, Santorini N, Piccinato A, Avascular necrosis of the femoral head: current trends. Ed. Springer Verlag, Milan, 2004; 147.

22. Seamon J, Keller T, Saleh J, Cui Q, The pathogenesis of nontraumatic osteonecrosis. Arthritis, 2012; 2012: $1-7$.

23. Sen RK, Management of avascular necrosis of femoral head at pre-collapse stage. Ind J Orthop., 2009; 43(1): 6-16.

24. Shu-Qing C, You-Jin C, Hou-Ming Z, Jian Q, Clinical efficacy of alendronate treatment of earlystage adult nontraumatic avascular necrosis of femoral head. Chin J Geriatr., 2011; 30(8): 661-663.
25. Takao M, Sugano N, Niishii T, Longitudinal quantitative evaluation of lesion size change in femoral head osteonecrosis using three- dimensional magnetic resonance imaging and image registration. $J$ Orthop Res.,2006; 24(2): 1231-1239.

26. Trăistaru MR, Kamal D, Kamal KC, Rogoveanu OC, Popescu M, Bondari S, Alexandru DO, Ionovici N, Grecu DC, Imaging and histopathological aspects in aseptic osteonecrosis of the femoral head. Rom $J$ Morphol Embryol., 2015; 56(4): 1447-1453.

27. Tripathy SK, Goyal T, Sen RK, Management of femoral head osteonecrosis: Current concept. Ind $J$ Orthop., 2015; 49(1): 28-45.

28. Young ML, Little DG, Kim HK, Evidence for using bisphosphonate to treat Legg-Calve-Perthes disease. Clin Orthop Relat Res., 2012; 470(9): 2462-2475. 